\title{
Late Bronze Age Socio-Economic and Political Organization, and the Hellenization of Cyprus
}

\author{
By Andreas G. Orphanides*
}

Cultural and social interactions in the Eastern Mediterranean during the Late Bronze Age involved trade, mercantile operations, migration, colonization and/or military engagement. The Mycenaean expansion in the Eastern Mediterranean found Cyprus occupying a strategic position in the sea routes between Greece and the Near East. The Mycenaeans as early as the fourteenth century BC began establishing entrepôt stations in Cyprus that facilitated their commercial interactions with the Near East. In the meantime, something equally important led them to pay more attention to the island, to gradually dominate over it, to achieve control over its territory, and to consequently Hellenize it. It was the fact that Cyprus was one of the most important copper sources in the Mediterranean. The discovery by the Mycenaeans that copper was readily available on the island, increased its importance considerably. A new type of economy and political organization emerged in Cyprus, based on the Mycenaean exploitation of copper. The new economic and political system caused an increase of settlements and population in the regions of copper exploitation, and it is reflected by the distribution of the settlements that aimed at serving the maximal exploitation of the copper sources for the benefit of the Mycenaeans. In other words, the distribution and organization of the settlement pattern during the Late Cypriot II and particularly in the Late Cypriot III periods reflect the complete economic and political control of and domination over Cyprus by the Mycenaeans.

When the Mycenaeans expanded in the Eastern Mediterranean, they found Cyprus occupying a strategic position in the sea routes between Greece and the Near East; they took advantage of it and, and early as the fourteenth century BC, they started establishing entrepôt stations in Cyprus that facilitated their commercial interactions with the Near East. ${ }^{1}$ In the meantime, something

\footnotetext{
* Professor of History, Archaeology and Anthropology, Department of Social and Behavioral Sciences, School of Humanities and Social Sciences, European University Cyprus, Nicosia, Cyprus.

1. S.W. Manning and L. Hulin, L., "Maritime Commerce and Geographies of Mobility in the Late Bronze Age of the Eastern Mediterranean: Problematizations," in The Archaeology of Mediterranean Prehistory, ed. E. Blake and A.B. Knapp (Malden, MA 2015), 270-302; A. B. Knapp, "Prehistoric Cyprus: A 'Crossroads' of Interaction?" in Multiple Meditterranean Realities: Current Approaches to Spaces, Resources, and Connectivities, ed. A. Lichtenberger and C. von Rüden (Paderborn 2015), 17-30; L. Steel, "Late Bronze Age Cyprus," in Oxford Handbook of the Ancient Levant, ed. M. Steiner and A. Killebrew (Oxford, 2014), 577-591; P. W. Stockhammer, "Levantine and Cypriot Pottery in Mycenaean Greece as Mirrors of Intercultural Contacts," in The Mediterranean Mirror. Cultural Contacts in the Mediterranean Sea between 1200 and 750 B.C. Conference, Heidelberg, 6th-8th October 2012, RGZM, ed. A. Babbi et al. (Mainz, 2015), 177-187; A. Bernard Knapp, The Archaeology of Cyprus: From Earliest Prehistory through the Bronze Age, Cambridge: , Cambridge University Press, 2013; I. Voskos and A. Bernard Knap, "Cyprus at the End of the Late Bronze Age: Crisis and Colonization or Continuity and Hybridization," AJA 112(4) (2008): 659-684; S. Sherratt,
} 
equally important led them to pay more attention to the island, to gradually dominate over it, to achieve control over its territory, and to consequently Hellenize it. It was the fact that Cyprus was one of the most important copper sources in the Mediterranean. ${ }^{2}$ The discovery by the Mycenaeans that a resource as valuable as copper was readily available on the island, increased its

"Immigration and Archaeology: Some Indirect Reflections," in Acta Cypria, Vol. 2, SIMA-PB 117, ed. P. Åström, (Jonsered, 1992), 316-347; M. Atzy, "Nomads in the Sea," in Res Maritimae: Cyprus and the Eastern Mediterranean from Prehistory through Late Antiquity, Cyprus American Archaeological Institute Monograph I, ed. S. Swiny, R. Hohlfelder, and H. W. Swiny, (Atlanta, 1997), 1-16; M. Atzy, "Routes, Trade, Boats and 'Nomads of the Sea'," in Mediterranean Peoples in Transition: Thirteenth to Tenth Centuries, ed. S. Gitin, A. Mazar, and E. Stern (Jerusalem, 1998), 439-448; K. Nicolaou, "The First Mycenaeans in Cyprus," in Acts of the International Symposiun: The Mycenaeans in the Eastern Mediterranean, ed. V. Karageorghis (Nicosia, 1973), 51-61; M. Iacovou, "The Greek Exodus to Cyprus: The Antiquity of Hellenism," Mediterranean Historical Review 14, no. 2 (1999): 1-28; M. Iacovou, "Cyprus at the Dawn of the First Millennium: Cultural Homogenization versus the Tyranny of Ethnic Identification," in Archaeological Perspectives on the Transmission and Transformation of Culture in the Eastern Mediterranean, Levant Suppl. 2, ed. J. Clarke (Oxford 2005), 125-134; M. Atzy, Nomads in the Sea" in Res Maritimae: Cyprus and the Eastern Mediterranean from Prehistory through Late Antiquity, Cyprus American Archaeological Institute Monograph I, ed. S. Swiny, R. Hohlfelder, and H. W. Swiny, (Atlanta, 1997), 1-16; V. Karageorghis, ed., Acts of the International Archaeological Symposium 'The Mycanaeans in the Eastern Mediterranean, Nicosia 27th March - 2nd April 1972 (Nicosia, 1973); V. Karageorghis, From the Stone Age to the Romans (London, 1982), 61-113; P. Åström, The Late Cypriote Bronze Age, SCE IV:IC (Lund, 1972); H. W. Catling, Cyprus in the Neolithic and Bronze Age Periods (CAH 1966), 56; P. Åström in SCE IV:1C, 289-414; A. Wace and C. Blegen in Klio 32 (1939), 131-147; Y. Lynn Holmes, "The Foreign Trade of Cyprus during the Late Bronze Age," in The Archaeology of Cyprus: Recent Developments, ed. N. Robertson (New Jersey, 1975), 90-110; J.D. Muhly, "The Late Bronze Age in Cyprus: A 25 Year Retrospect," in Archaeology in Cyprus 1960-1985, ed. V. Karageorghis (Nicosia, 1985), 20-46; V. Karageorghis and J.D. Muhly, ed., Cyprus at the Close of the Late Bronze Age (Nicosia, 1984); P. Åström, "Trade in the Late Bronze Age," in Early Society in Cyprus, ed. E. Peltenburg (Edinburgh, 1989), 202-208; J. L. Myres, Handbook of the Cesnola Collection of Antiquities from Cyprus (New York: The Metropolitan Museum of Art, 1914).

2. V. Kassianidou, "Mining Landscapes of Prehistoric Cyprus," Metalla 20:2 (2013), 3645; H.W. Catling, Cypriot Bronzework in the Mycenaean World (Oxford, 1964), 17; J. Du Plat Taylor, "Mines Where the Mycanaeans Got Their Copper Discovered in Cyprus," ILN 196 (1940), 251; D. Panagiotopoulos, "The Stirring Sea: Conceptualising Transculturality in the Late Bronze Age Eastern Mediterranean," in Intercultural Contacts in the Ancient Mediterranean, Orientalia Lovaniensia Analecta 202, ed. K. Duistermaat and I. Regulski (Louvain 2011), 3151; A.B. Knapp, "Prehistoric Cyprus: A 'Crossroads' of Interaction?" in Multiple Meditterranean Realities: Current Approaches to Spaces, Resources, and Connectivities, ed. A. Lichtenberger and C. von Rüden (Paderborn 2015), 17-30; A.G. Orphanides, "Late Bronze

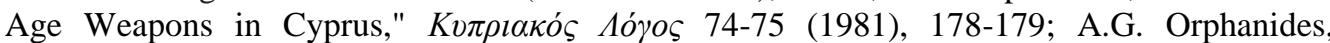
"Southern Cyprus in the Late Bronze Age: A Regional Perspective," Archaeologia Cypria I (1985) 23-27; J.D. Muhly, R. Maddin, and V. Karageorghis, Early Metallurgy in Cyprus 4000 500 B.C., Acta of the International Archaeological Symposium (Larnaca 1981); L. Vagnetti and F.L. Schiavo, "Late Bronze Age Long Distance Trade in the Mediterranean: The Role of the Cypriots," in Early Society in Cyprus, ed. E. Peltenburg (Edinburgh, 1989), 217-243; J.D. Muhly, "The Organization of the Copper Industry in Late Bronze Age Cyprus," in Early Society in Cyprus, ed. E. Peltenburg (Edinburgh, 1989), 298-314; S. Sherrat, "Circulation of Metals and the End of the Bronze Age in the Eastern Mediterranean," in Metals Make the World Go Round: The Supply and Circulation of Metals in Bronze Age Europe, ed. C. F. Pare (Oxford, 2000), 82-98. 
importance considerably. Timber, as the main material for shipbuilding, was obviously another important resource for them on the island.

It is very well established that bronze tools and vessels, and particularly bronze weapons were extensively used in the Mycenaean culture. Especially bronze weapons were primarily and vitally important to the Mycenaeans for their military expeditions. It is worthy to mention that a comparison between the typical Cypriot weapons and the Mycenaean ones clearly shows that the island lagged far behind the Mycenaeans in the design, manufacture, technology and effectiveness of its weapons. ${ }^{3}$ Bearing this in mind, we may better understand the level of resistance that the Mycenaeans would encounter during the process of establishing themselves, exploiting and dominating over the island.

A new type of economy and political organization emerged in Cyprus, based on the Mycenaean exploitation of copper. ${ }^{4}$ The new economic and political system caused an increase of settlements and population in the regions of copper exploitation, and it is reflected by the distribution of the settlements that aimed at serving the maximal exploitation of the copper sources for the benefit of the Mycenaeans. ${ }^{5}$ In other words, the distribution and organization of the settlement pattern during the Late Cypriot II and particularly in the Late Cypriot III periods reflect the complete economic and political control of and domination over Cyprus by the Mycenaeans.

The settlements were distributed in a pattern of distinct clusters. ${ }^{6}$ Each cluster included a wealthy coastal urban center with a harbor. Such clusters of

3. H.W. Catling, Cypriot Bronzework in the Mycenaean World (Oxford, 1964), 17; A.G.

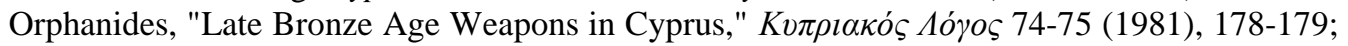
A.M. Snodgrass, Arms and Armour of the Greeks (London 1967); L. Steel, Cyprus before History: From the Earliest Settlers to the End of the Bronze Age (London, 2004), 196.

4. E. Peltenburg, ed., Early Society in Cyprus (Edinburgh, 1989); A. Bernard Knapp, "Cyprus, Crete, and Copper: A Comment on Catling's Paradox," Report of the Department of Antiquities, Cyprus (1990), 55-63; P. Åström, "The Economy of Cyprus and its Development in the 2nd Millenium," Arch Viva II, no. 3 (1969): 73-80. A. B.d Knapp, Copper Production and Divine Protection: Archaeology, Ideology and Social Complexity in Bronze Age Cyprus, SIMA Pocket-Book 42 (Göteborg, 1986).

5. L. Steel, "Exploring Regional Settlement on Cyprus in the Late Bronze Age: the Rural Hinterland," in The Formation of Cyprus in the 2nd Millennium BC. Studies in Regionalism during the Middle and Late Bronze Ages, ed. I. Hein (Vienna, 2009), 133-143; V. Kassianidou, "Mining Landscapes of Prehistoric Cyprus,"Metalla 20, no. 2 (2013), 36-45; V. Kassianidou, "The Production and Trade of Cypriot Copper in the Late Bronze Age: An Analysis of the Evidence," Pasiphae VII (2013), 133-146; H.W. Catling, "Patterns of Settlement in Bronze Age Cyprus," OpAth IV (1963), 142; K. Nicolaou, The Historical Topography of Kition (SIMA XLIII) (Göteborg, 1976); P. Åström, "Dromolaxia, Locality "Trypes," RDAC (1977), 110-112: A. G. Orphanides, "The Political and Economic Implications of the Mycaenaean Presence in Cyprus," Acts of the Third International Congress of Cypriot Studies (Nicosia, 1985), 379-385.

6. A.G. Orphanides, "Southern Cyprus in the Late Bronze Age: A Regional Perspective," Archaeologia Cypria I (1985), 23-27; N.P. Stanley Price, Early Prehistoric Settlement in Cyprus 6500-3000 B.C. (BAR, International Series), 65 (Oxford, 1979), 81; P. Åström et al., in SIMA XLV:1-7; V. Karageorghis and O. Masson, in Studi Ciprioto e Rapporti di Scavo I (Biblioteca di Antichita Cipriote, 1971), 237-247; H.W. Catling, Cypriot Bronzework in the Mycenaean World (Oxford, 1964), 17; J. Johnson, Maroni de Chypre, SIMA LIX (Göteborg, 1980); G. Cadogan, "Maroni and the Late Bronze Age of Cyprus," in Cyprus at the Close of 
settlements can be found at the Morphou bay and Polis tis Khrysokhous on the northern coast, whereas such clusters of settlements on the eastern coast could be found at Enkomi, at the modern village of Pyla, at Kition at modern Larnaca, and at Hala Sultan Tekke on the Larnaca Salt Lakes, where, at that time, there was an open inlet and a fine harbor. Harbors can also be documented in the other mentioned clusters of settlements, with Dhekelia for the Pyla cluster and Kition for the Kition one. As for the southern coast, a cluster of settlements occupied the area around Maroni and Kalavassos that included the Pendaskinos and Vassilikos rivers. The relatively large quantity of Aegean imports at these two sites, suggest that they attracted much of the trade with the West, so that a harbor functioned there as it was the case with the other clusters. Another concentration of important sites is on both sites of the Kourris river; the Episkopi settlement is on the western bank, whereas the Erimi group is on the eastern bank. A cluster of settlements is also found around Kouklia (Palaepaphos). In the last two clusters, harbors may have existed in the same manner as in the other clusters on the southern coast. Finally, a cluster of settlements can be found at Maa-Palaeokastro. It is possible that additional such clusters existed elsewere in Cyprus as well.

The coastal urban centers occupied prominent positions within these clusters of settlements; this is obvious by considering the wealth unearthed in excavations, their function as industrial cities engaged in copper refining and production of bronzework, ${ }^{7}$ and the evidence of literacy. Where harbors cannot easily be located, river mouths were well suited to the needs of shipping. For example, such river mouths can be observed at Kivisil on the Pouzis river, Erimi and Episkopi on the Kourris river, and Kouklia on the Dhiarrizos. The coastal urban centers obviously provided communication with foreign regions, thus promoting trade with the Aegean, Asia Minor, Syria-Palestine, and Egypt. But above all, they managed and controlled the extraction, smelting, refining and export of copper for satisfying the relevant needs of the Mycenaeans

the Late Bronze Age, ed. V. Karageorgis and J.D. Muhly (1984), 1-10; V. Karageorghis and M. Demas, in RDAC (1981), 135-141; F.G. Maier, "Evidence for Mycenaean Settlement at Old Paphos," Acts of the International Archaeological Symposium 'The Mycanaeans in the Eastern Mediterranean,' Nicosia 27th March - 2nd April 1972 (Nicosia, 1973); M. Demas, Pyla Kokkinokremmos and Maa-Palaeokastro: Two Fortified Settlements of the end of the 13th Century B.C. in Cyprus, Ph.D. diss., Univ. of Cincinnati, 1984); A. South, "Kalavassos-Ayios Dhimitrios and the Late Bronze Age in Cyprus," in Cyprus at the Close of the Late Bronze Age (1984), ed. V. Karageorgis and J.D. Muhly, 11-18; S. Swiny, "Bronze Age Settlement Patterns in Southwest Cyprus," Levant 13 (1981), 51-87; O. Negbi, "The Climax of Urban Development in Bronze Age Cyprus," RDAC (1986), 97-121.

7. J.D. Muhly, R. Maddin, and V. Karageorghis, Early Metallurgy in Cyprus 4000-500 B.C., Acta of the International Archaeological Symposium (Nicosia 1981); V. Kassianidou, "The Production and Trade of Cypriot Copper in the Late Bronze Age: An Analysis of the Evidence," Pasiphae VII (2013), 133-146; H.W. Catling, Cypriot Bronzework in the Mycenaean World (Oxford, 1964) 21; R.S. Merrillees in RDAC (1982), 244-251; E. Herscher in RDAC (1980), 18-20; P. Rabar, The Organization and Development of Early Copper Metallurgy in the Polis Region, Western Cyprus, (Ph.D. diss., Penn. State Univ., 1984); P. Rabar, "Early Copper Production in the Polis Region, Western Cyprus," J Field A 14 (1987), 297-312; R.F. Tylecote, "The Late Bronze Age Copper and Bronze Metallurgy at Enkomi and Kition," EMC (Nicosia, 1981), 81-103. 
themselves and the needs of markets in the Eastern Mediterranean served by them. ${ }^{8}$

Coastal urban centers, such as Enkomi, Dhekelia, Kition, Hala Sultan Tekke, Maroni, Kalavassos, etc. offer an excellent idea of their material prosperity and the tremendous number of material goods imported from abroad. Mycenaean trade is very well documented in almost all clusters of settlements, judging especially from the Mycenaean pottery and other artifacts reaching their peak in LCIII and found at almost all Late Cypriot sites in these clusters. ${ }^{9}$ This imported Mycenaean material was obviously distributed to the various sites within each cluster of settlements via the major coastal urban centers. The rivers were probably vitally related to certain settlements in all clusters. This can easily be understood, considering the importance of water supply to the survival of the settlements. It seems likely that some of these settlements were exclusively engaged with agriculture, producing so the required subsistence for consumption in the coastal urban centers, and in other

8. V. Kassianidou, "The Production and Trade of Cypriot Copper in the Late Bronze Age: An Analysis of the Evidence," Pasiphae VII (2013), 133-146; L. Vagnetti and F.L. Schiavo, "Late Bronze Age Long Distance Trade in the Mediterranean: The Role of the Cypriots," in Early Society in Cyprus, ed. E. Peltenburg (Edinburgh, 1989), 217-243; G.F. Bass, "A Bronze Age Shipwreck at Ulu Burum (Kas):1984 Campaign," AJA 90 (1986): 269-296; J.D. Muhly, "The Role of Cyprus in the Economy of the Eastern Mediterranean During the Second Millenium B.C.," in Acts of the International Archaeological Symposium 'Cyprus Between the Orient and Occident', ed. V. Karageorghis (Nicosia, 1986), 45-60; C. Pullak, "The Bronze Age Shipwreck at Ulu Burun, Turkey: 1985 Campain," AJA 92 (1988): 1-37; Z.A. Stos-Gale, N.H. Gale and U. Zwicker, "The Copper Trade in the South-East Mediterranean Region. Preliminary Scientific Evidence," RDAC (1986): 122-144; N.H. Gale, "Late Bronze Age Copper Oxhide Ingots and the Ancient Exploitation of the Cypriot Copper Deposits in Relation to Bronze Age Trade in the Mediterranean: New Results," 3rd International Congress of Cypriot Studies, (Nicosia, 1985).

9. A. B. Knapp, The Archaeology of Cyprus: From Earliest Prehistory through the Bronze Age (Cambridge University Press, 2013); L. Steel, "Exploring Regional Settlement on Cyprus in the Late Bronze Age: the Rural Hinterland," in The Formation of Cyprus in the 2nd Millennium BC. Studies in Regionalism During the Middle and Late Bronze Ages, ed. I. Hein, (Vienna, 2009), 133-143; I. Voskos and A. Bernard Knap, "Cyprus at the End of the Late Bronze Age: Crisis and Colonization or Continuity and Hybridization," AJA 112(4) (2008): 663-676; P. Keswani, "Beyond Emulation and Hierarchy: Diverse Expressions of Social Identity in Late Cypriot Mortuary Ritual," in Mediterranean Crossroads, ed. S. Antoniadou and A. Pace (Athens and Oxford, 2007), 509-535; P. Keswani, Mortuary Rituals and Society in Bronze Age Cyprus. Monographs in Mediterranean Archaeology 9, (London, 2004), 127-127; L. Steel, "A Rappraisal of the Distribution, Context and Function of Mycaenaean Pottery in Cyprus," in La Ceramique Mycénienne de l'Égée au Levant. Travvaux de la Maison de l' Orient 41, ed. J. Balensi, J.-Y. Monchambert, and S. Müller-Celku (Lyon, 20014), 69-85; V. Karageorghis ed. Acts of the International Archaeological Symposium 'The Mycanaeans in the Eastern Mediterranean,' Nicosia 27th March - 2nd April 1972 (Nicosia, 1973); J.D. Muhly, "The Late Bronze Age in Cyprus: A 25 Year Retrospect," in Archaeology in Cyprus 19601985; V. Karageorghis, ed. (Nicosia, 1985), 20-46; V. Karageorghis, From the Stone Age to the Romans (London, 1982), 61-113; P. Åström, The Late Cypriote Bronze Age, SCE IV:IC (Lund, 1972); E. Vermeule and F. Wolsky, "New Aegean Relations with Cyprus: The Minoan and Mycenaean Pottery from Toumba tou Skourou, Morphou," Proc Amer Phil Soc 122 (1978), 293-317; B. Kling, Mycenaean IIIC:1b and Related Pottery in Cyprus (Ann Arbor, 1986). 
settlements that were primarily engaged with the extraction and smelting of copper.

A number of settlements in each cluster were located near copper mines. It seems likely that their population was primarily involved with extracting and smelting copper. They were actually placed on lines of communication with the rich industrial coastal urban centers, so that raw copper material extracted by them could be dispatched to those centers. ${ }^{10}$ An argument has occasionally been raised that possibly imported copper ore was smelted at Cypriot sites. Considering the fact that Cyprus itself was a main source of copper in the Eastern Mediterranean, such argument does not seem to be reasonable; something that can also be testified with chemical characterization. ${ }^{11}$ Copperbearing ores occur for each cluster of settlements, such as at Limni Mines, Skouriotissa, Apliki and Ambelikou; at the areas of Troulli, Sha, Kornos, Pano Lefkara and Ora; at Khirokitia, Kalavassos, Monagroulli, Mathikoloni, etc. On the other hand, remains of slag at several sites, such as Enkomi, Kition, Hala Sultan Tekke, Arpera, Klavdhia, Maroni, Kalavassos, Mari, Moni, etc. indicate that copper ore was mined, whereas finds of industrial equipment at the coastal urban centers show that it was smelted, it was made into manufactured goods and/or ingots, and it was exported. ${ }^{12}$ This activity was the primary basis of the economy, which obviously served primarily the Mycenaeans on international basis, and secondarily the local population.

The flow of raw copper, timber and agricultural surplus on one hand, and the flow of imported pottery and other artifacts on the other, are characteristic of the nature of interactions between sites, and of the overall economic and political system. ${ }^{13}$ It seems that a certain pattern of interaction and a certain

10. V. Karageorghis, The End of the Bronze Age in Cyprus (Nicosia, 1990); H. W. Catling, Cyprus in the Neolithic and Bronze Age Periods (CAH, 1966), 91; Y. Lynn Holmes, "The Foreign Trade of Cyprus During the Late Bronze Age," in The Archaeology of Cyprus: Recent Developments, ed. N. Robertson (New Jersey, 1975), 91; V. R. Desborough, The Last Mycenaeans and their Successors (Oxford, 1964).

11. N.H. Gale, "Late Bronze Age Copper Oxhide Ingots and the Ancient Exploitation of the Cypriot Copper Deposits in Relation to Bronze Age Trade in the Mediterranean: New Results," 3rd International Congress of Cypriot Studies, (Nicosia, 1985); V. Kassianidou, "The Production and Trade of Cypriot Copper in the Late Bronze Age: An Analysis of the Evidence," Pasiphae VII (2013), 133-146; V. R. Desborough, The Last Mycenaeans and their Successors (Oxford, 1964).

12. V. Kassianidou, "Mining Landscapes of Prehistoric Cyprus," Metalla 20, no. 2 (2013), 36-45; V. Kassianidou, "The Production and Trade of Cypriot Copper in the Late Bronze Age: An Analysis of the Evidence," Pasiphae VII (2013), 133-146; P. W. Stockhammer, "Levantine and Cypriot Pottery in Mycenaean Greece as Mirrors of Intercultural Contacts," in The Mediterranean Mirror. Cultural Contacts in the Mediterranean Sea between 1200 and 750 B.C. Conference, Heidelberg, 6th-8th October 2012, RGZM, ed. A. Babbi et al. (Mainz, 2015), 177-187; J.D. Muhly, R. Maddin, and V. Karageorghis, Early Metallurgy in Cyprus 4000-500 B.C., Acta of the International Archaeological Symposium (Nicosia 1981); J.D. Muhly, "The Organization of the Copper Industry in Late Bronze Age Cyprus," in Early Society in Cyprus, ed. E. Peltenburg (Edinburgh, 1989), 298-314; V. R. Desborough, The Last Mycenaeans and their Successors (Oxford, 1964).

13. L. Steel, "A Rappraisal of the Distribution, Context and Function of Mycaenaean Pottery in Cyprus," in La Ceramique Mycénienne de l' Égée au Levant. Travvaux de la Maison de l' Orient 41, ed. J. Balensi, J.-Y. Monchambert, and S. Müller-Celku (Lyon, 2014), 69-85; 
politico-economic model recurs in each cluster of settlements, where the coastal urban centers -- which were entirely controlled by the Mycenaeans -can be classified as high-order centers, and the other settlements within each cluster as lower-order centers.

Low order centers were responsible for extracting and probably partly processing the ore, either at the area of the mines or within the settlements; the refining, sometimes smelting, and manufacturing of ingots and/or copper artifacts took place in the coastal urban and industrial centers, i.e. the highorder centers. The immediate consequence was that these centers provided the industrial units for the final stages of copper refining, smelting and manufacturing. This activity had obviously both economic and political implications. Tin-bronze was also widely used in Cyprus throughout the Late Bronze Age. However, since there is no evidence of any tin sources in Cyprus, it seems reasonable to assume that tin was imported to the island at that time. ${ }^{14}$ Therefore, the high-order centers had as well the supply of tin under their control. Timber and agricultural goods obviously moved from low-order centers to the high-order centers. On the other hand, imported pottery and other artifacts moved in the opposite direction, so that these types of material were distributed by the high-order centers to the low-order centers. This directional distribution was obviously the natural consequence of the fact that these types of material were imported via the harbors of the high-order centers; their distribution was therefore controlled by these centers.

The organization and interaction of the settlements in each cluster seem to follow a Dendritic Central-Place model. According to this model, each highorder center develops lattices of low-order centers within a uniform resource distribution and equal transport facility in all directions. The pattern of this model is determined by the flow of copper, timber and agricultural goods on one hand, and of imported artifacts on the other. It also considers the role that a Mycenaean power based outside the system played in this framework. The Dendritic Central-Place model includes up to a considerable extent the

V. Kassianidou, "The Production and Trade of Cypriot Copper in the Late Bronze Age: An Analysis of the Evidence," Pasiphae VII (2013), 133-146; A. B. Knapp, "Production, Exchange and Socio-Political Complexity in Bronze Age Cyprus," Oxf J A 5 (1986), 35-60; J.D. Muhly, "The Organization of the Copper Industry in Late Bronze Age Cyprus," in Early Society in Cyprus, ed. E. Peltenburg (Edinburgh, 1989), 298-314; T. Stech, "Urban Metallurgy in Late Bronze Age Cyprus," EMC (Nicosia, 1981), 105-116; A.K. South, "From Copper to Kingship: Aspects of Bronze age Society Viewed from the Vasilikos Valley," in Early Society in Cyprus, ed. E. Peltenburg (Edinburgh, 1989), 315-324; P. Keswani, Mortuary Rituals and Society in Bronze Age Cyprus. Monographs in Mediterranean Archaeology 9 (London, 2004).

14. V. Kassianidou, "The Trade of Tin and the Island of Copper," in Le Problème de l' Etain a l' Origine de la Métallurgie/The Problem of Early Tin. XIV Congress UISPP, Section 11, 2nd Colloquium, BAR International Series S1199, ed. A. Giumlia-Mair and F. Lo Schiavo (Liège, 2003), 109-119; H. W. Catling, Cyprus in the Neolithic and Bronze Age Periods (CAH 1966), 71; J.D. Muhly, "Copper and Tin: The Distribution of Mineral Resources and the Nature of the Metals Trade in the Bronze Age, "Transactions of the Connecticut Academy of Arts and Sciences 43 (1973): 155-535; T.S. Wheeler, J.D. Muhly and R. Maddin, "Mediterranean Trade in Copper and Tin in the Late Bronze Age," Ann Ist It Num 26 (1979): 139-152. 
Christaller's Administrative Principle. ${ }^{15}$ According to this principle, the model is designed for the benefit of the ruling elite rather than of the small producer (in the case of copper, timber and agricultural goods) or consumer (in the case of imported artifacts). It is bounded, with the low-order centers located within the hinterland of a single high-order center. Transactions and interactions are direct between the major center and the peripheral secondary ones. Each highorder center controls the lower-order ones and the hinterland exclusively, with minimal competition between the high-order centers regarding the low-order centers. Therefore, this system of economic and political organization seems to be highly efficient in forming discrete political-administrative units. ${ }^{16}$ Apart from this administrative aspect, the model is also characterized by the existence of a Mycenaean power/elite based outside the system and a commodity flow that follows a dendritic pattern. The export of a primary commodity, i.e. copper, creates a distinctive regional economic organization, labeled a dendritic system.

Spatially, the pattern of centers resembles a branching tree or dendrite, with the Mycenaean power/elite being the highest-level entity, and with also a number of high-order centers, each one in control of a number of low-order centers. Neither concentration of political and economic power, nor control of information allows competition within the hinterland, whereas the high-order center is in a monopoly position. In addition, an international market elite, which either it is Mycenaean or it is served by the Mycenaeans, is based outside the system. Since rural goods do not flow with regularity across rural markets, peasants at the peripheral ends of dendritic systems specialize in producing goods for a broad, often international, market and consume other goods from that market. But at the same time they produce their own subsistence goods. ${ }^{17}$

In a Dendritic Central-Place model it is expected that the elite political groups are located in centers in which the control over the regional economic system can be maximized. Obviously, the only point from which the greatest political control can be exercised is the high-order center. Of course in the case of Late Bronze Age Cyprus, the elite groups located in the high-order centers are actually the extension of the actual political and economic elite that is outside Cyprus, i.e. the Mycenaean. It seems likely that the religious

15. W. Christaller, Die Zentralen Orte in Süddeutschland [The central places in southern Germany] (Jena, 1933); C. A. Smith, "Regional Economic Systems: Linking Geographical Models and Socioeconomic Problems," in Regional Analysis: Economic Systems, Vol. I, ed. C.R. Smith (New York, 1976), 3-68; V. L. Scamborough, and J. E. Clark, ed., The Political Economy of Ancient Mesoamerica (Albuquerque, 2007).

16. W. Bray, in E.Z. Vogt and R.M. Leventhal, ed., Prehistoric Settlement Pattern, Harvard University (Cambridge, 1983), 171; C. A. Smith, "Economics and Marketing Systems: Models for Economic Geography," Annual Review of Anthropology 3 (1974): 175. In the case of possible clusters of settlements in the interior of the island, e.g. Idalion, such clusters can be accommodated in the proposed dendritic model, provided that the major center in each one of them was in fact controlled by a high-order center on the coast.

17. K.B. Kelley, "Dendritic Central-Place Systems and the Regional Organization of Navajo Trading Posts," in Regional Analysis: Economic Systems, Vol. I, ed. C.R. Smith (New York, 1976), 219-254. 
institutions in general and the priesthood in particular were the major components of the political and economic ruling elite. This is clearly indicated, for example at Kition, where in its industrial quarter at Kathari on its northern section, the copper industrial workshops were located within the area of the sacred compound that was obviously controlled by the priesthood. ${ }^{18}$ This kind of political and economic elite played a major role due to its nature and function towards the domination of the Greek Mycenaean religion, language, art and culture in general over the local population. This consequently led to the Hellenization of the territories that they controlled within the framework of a Central-Place Dendritic model of political and economic organization.

Mycenaean migration to or colonization of Cyprus in the Late Bronze Age, interrelated to a Hellenization perspective, based primarily on the superiority of the incoming Mycenaeans over the local Cypriot population, have been deep and central in Cypriot archaeology. ${ }^{19}$ In addition, and in reaction to both colonization and Hellenization models, a mercantile model had emerged, characterized by and attributed to a localized and entrepreneurial Mediterranean maritime trade. ${ }^{20}$ On the other hand, a hybridization model had emerged after critiquing and contesting the above models, based on the notion of social admixture, and on an enlargement and contribution of different groups of people of differing origins. Employing the principle of avoiding unitary

18. K. Nicolaou, The Historical Topography of Kition, SIMA XLIII (Göteborg, 1976), 308; V. Karageorghis, View from the Bronze Age: Mycenaean and Phoenician Discoveries at Kition (New York, 1976), 26-57; F.G. Maier, "Priest Kings in Cyprus," in Early Society in Cyprus, ed. E. Peltenburg (Edinburgh, 1989), 376-391; T. Stech, R. Maddin, and J.D. Muhly, "Copper Production at Kition in the Late Bronze Age," Kition I (1985), 388-402; R.F. Tylecote, "Copper Working at Kition," Kition I (1985), 430; A. B. Knapp, Copper Production and Divine Protection: Archaeology, Ideology and Social Complexity in Bronze Age Cyprus, SIMA Pocket-Book 42 (Göteborg, 1986).

19. N. Leriou, "Locating Identities in the Eastern Mediterranean during the Late Bronze Age-Early Iron Age: The Case of 'Hellenised' Cyprus," in Mediterranean Crossroads, ed. S. Antoniadou and A. Pace (Athens and Oxford, 2007), 563-591; N. Leriou, "The Mycenaean Colonisation of Cyprus under the Magnifying Glass: Emblematic Indica versus Defining Criteria at Paphos," in SOMA 2001: Symposium on Mediterranean Archaeology, ed. G. Muskett, A. Koltsida, and M. Georgiadis (Oxford, 2002), 169-177; M. Iacovou, "Cyprus at the Dawn of the First Millennium: Cultural Homogenization Versus the Tyranny of Ethnic Identification," in Archaeological Perspectives on the Transmission and Transformation of Culture in the Eastern Mediterranean. Levant Suppl. 2, ed. J. Clarke (Oxford 2005), 125-134; M. Iacovou, "The Greek Exodus to Cyprus: The Antiquity of Hellenism," Mediterranean Historical Review 14(2) (1999): 1-28; K. Nicolaou, "The First Mycenaeans in Cyprus," in Acts of the International Symposiun: The Mycenaeans in the Eastern Mediterranean, ed. V. Karageorghis, (Nicosia, 1973), 51-61; V. Karageorghis, "Hellenism beyond Greece: Cyprus," in Greek Archaeology without Frontiers, ed. I. A. Todd D. Komini-Dialeti, and D. Hatzivassiliou (Athens, 2002), 31-43.

20. S. Sherratt, "Immigration and Archaeology: Some Indirect Reflections," in Acta Cypria, Vol. 2, SIMA-PB 117, ed. P. Åström, (Jonsered, 1992), 316-347; M. Atzy, "Nomads in the Sea" in Res Maritimae: Cyprus and the Eastern Mediterranean from Prehistory through Late Antiquity, Cyprus American Archaeological Institute Monograph I, ed. S. Swiny, R. Hohlfelder, and H. W. Swiny, (Atlanta, 1997), 1-16; M. Atzy, "Routes, Trade, Boats and 'Nomads of the Sea'," in Mediterranean Peoples in Transition: Thirteenth to Tenth Centuries, ed. S. Gitin, A. Mazar, and E. Stern (Jerusalem, 1998), 439-448. 
views, I would say that all the above models and perspectives together, most likely synthesize a holistic perspective of the issue. ${ }^{21}$

Hellenization of Cyprus, having its origins in the Late Cypriot period, developed thereafter gradually through time. The mercantile and entrepreneurial operations of the Mycenaeans in the Eastern Mediterranean, together with the exploitation and trade of copper, were the starting points for their presence in Cyprus. The Mycaenaeans, who within the framework of the Dendritic CentralPlace model that I described above, acted originally as controlling economic and political elite outside the system, and after gradual migration, efforts of colonization, and eventual economic and political domination over the coastal urban/high order centers and their regions, dominated over Cyprus, leading so to its gradual Hellenization, that also involved, in a lower scale, other regional social and cultural elements and influences. Since then, Cyprus has been facing throughout its history the so called "Cyprus Problem", with various powers at different times aiming at controlling and being benefited from its geostrategic position and resources on one side, and the people of Cyprus defending their Hellenic identity and culture on the other.

\section{Bibliography}

Åström, P. "Trade in the Late Bronze Age." In Early Society in Cyprus, Edited by E. Peltenburg. Edinburgh: University of Edinburgh, 1989.

Åström, P. The Late Cypriote Bronze Age: Architecture and Pottery, SCE IV:IC. Lund: Swedish Cyprus Expedition, 1972.

Åström, P. "Dromolaxia, Locality 'Trypes'." RDAC (1977), 110-112

Atzy, M. "Nomads in the Sea." In Res Maritimae: Cyprus and the Eastern Mediterranean from Prehistory through Late Antiquity, Cyprus American Archaeological Institute Monograph I, Edited by S. Swiny, R. Hohlfelder, and H. W. Swiny. Atlanta: Scholars Press, 1997.

Atzy, M. "Routes, Trade, Boats and 'Nomads of the Sea'." In Mediterranean Peoples in Transition: Thirteenth to Tenth Centuries, Edited by S. Gitin, A. Mazar, and E. Stern Jerusalem: Israel Exploration Society, 1998.

Bass, G. F. "A Bronze Age Shipwreck at Ulu Burum (Kas): 1984 Campaign." AJA 90 (1986): 269-296.

Bray, W. "Landscape with figures: Settlement Patterns Locational Models and Politics in Mesoamerica. In Prehistoric Settlement Patterns: essays in honor of Gordon R. Willey, Edited by E.Z. Vogt and R.M. Leventhal, Cambridge: Harvard University, 1983.

Cadogan, G. "Maroni and the Late Bronze Age of Cyprus." In Cyprus at the Close of the Late Bronze Age, Edited by V. Karageorgis and J.D. Muhly. Nicosia: A. G. Leventis Foundation, 1984.

Catling, H. W. Cypriot Bronzework in the Mycenaean World. Oxford: Clarendon Press, 1964.

Catling, H. W. Cyprus in the Neolithic and Bronze Age Periods. Cambridge Ancient History. Cambridge: University of Cambridge, 1966.

21. I. Voskos and A. Bernard Knap, "Cyprus at the End of the Late Bronze Age: Crisis and Colonization or Continuity and Hybridization," AJA 112, no.4 (2008): 659-684. 
Christaller, W. Die Zentralen Orte in Süddeutschland [The central places in southern Germany]. Jena: Gustav Fischer, 1933.

Demas, M. Pyla Kokkinokremmos and Maa-Palaeokastro: Two Fortified Settlements of the end of the 13th Century B.C. in Cyprus. Ph.D. diss., University of Cincinnati, 1984.

Desborough, V. R. The Last Mycenaeans and their Successors. Oxford: Clarendon Press, 1964.

Gale, N. H. "Late Bronze Age Copper Oxhide Ingots and the Ancient Exploitation of the Cypriot Copper Deposits in Relation to Bronze Age Trade in the Mediterranean: New Results." 3rd International Congress of Cypriot Studies. Nicosia: Department of Antiquities, 1985.

Holmes, L. Y. "The Foreign Trade of Cyprus During the Late Bronze Age." In The Archaeology of Cyprus: Recent Development, Edited by N. Robertson. New Jersey: Noyes Press, 1975.

Iacovou, M. "Cyprus at the Dawn of the First Millennium: Cultural Homogenization versus the Tyranny of Ethnic Identification." In Archaeological Perspectives on the Transmission and Transformation of Culture in the Eastern Mediterranean, Levant, Suppl. 2, Edited by J. Clarke. Oxford: Council for British Research in the Levant and Oxbow, 2005.

Iacovou, M. "The Greek Exodus to Cyprus: The Antiquity of Hellenism." Mediterranean Historical Review 14, no. 2 (1999): 1-28.

Johnson, J. Maroni de Chypre. SIMA LIX. Göteborg, 1980.

Karageorghis V. and J. D. Muhly, eds. Cyprus at the Close of the Late Bronze Age. Nicosia, 1984.

Karageorghis, V. ed. Acts of the International Archaeological Symposium 'The Mycanaeans in the Eastern Mediterranean,' Nicosia 27th March - 2nd April 1972. Nicosia: Department of Antiquities, 1973.

Karageorghis, V. From the Stone Age to the Romans. London: Thames \& Hudson, 1982.

Karageorghis, V. The End of the Bronze Age in Cyprus. Nicosia: Pierides Foundation, 1990.

Karageorghis, V. View from the Bronze Age: Mycenaean and Phoenician Discoveries at Kition. New York: Dutton, 1976.

Karageorghis, V. and M. Demas. Excavations at Pyla- Kokkinokremos. RDAC (1981), 135-141.

Kassianidou, V. "Mining Landscapes of Prehistoric Cyprus." Metalla 20, no. 2 (2013): 36-45.

Kassianidou, V. "The Production and Trade of Cypriot Copper in the Late Bronze Age: An Analysis of the Evidence." Pasiphae VII (2013): 133-146.

Kassianidou, V. "The Trade of Tin and the Island of Copper." In Le Problème de l' Etain a l' Origine de la Métallurgie/The Problem of Early Tin. XIV Congress UISPP, Section 11, 2nd Colloquium, BAR International Series S1199, Edited by A. Giumlia-Mair and F. Lo Schiavo. Oxford: Archaeopress, 2003.

Kelley, K.B. "Dendritic Central-Place Systems and the Regional Organization of Navajo Trading Posts," in Regional Analysis: Economic Systems, Vol. I, Edited by C.R. Smith. New York, 1976.

Keswani, P. "Beyond Emulation and Hierarchy: Diverse Expressions of Social Identity in Late Cypriot Mortuary Ritual." In Mediterranean Crossroads, Edited by S. Antoniadou and A. Pace. Athens and Oxford: Pierides Foundation and Oxbow, 2007. 
Knapp, A. B. "Prehistoric Cyprus: A 'Crossroads' of Interaction?" In Multiple Mediterranean Realities: Current Approaches to Spaces, Resources, and Connectivities, Edited by A. Lichtenberger and C. von Rüden. Paderborn: Ferdinand Schöningh, 2015.

Knapp, A. B. "Production, Exchange and Socio-Political Complexity in Bronze Age Cyprus." Oxford Journal of Archaeology 5 (1986): 35-60.

Knapp, A. B. Copper Production and Divine Protection: Archaeology, Ideology and Social Complexity in Bronze Age Cyprus, SIMA Pocket-Book 42. Göteborg: Paul Åströms Förlag, 1986.

Knapp, A. B. The Archaeology of Cyprus: From Earliest Prehistory through the Bronze Age, Cambridge, Cambridge University Press, 2013.

Leriou, N. "Locating Identities in the Eastern Mediterranean during the Late Bronze Age-Early Iron Age: The Case of 'Hellenised' Cyprus." In Mediterranean Crossroads, Edited by S. Antoniadou and A. Pace. Athens and Oxford, 2007.

Leriou N. "The Mycenaean Colonisation of Cyprus under the Magnifying Glass: Emblematic Indica versus Defining Criteria at Paphos." In SOMA 2001: Symposium on Mediterranean Archaeology, ed. G. Muskett, A. Koltsida, and M. Georgiadis. Oxford, 2002.

Manning, S. W. and L. Hulin, L. "Maritime Commerce and Geographies of Mobility in the Late Bronze Age of the Eastern Mediterranean: Problematizations." In The Archaeology of Mediterranean Prehistory, Edited by E. Blake and A.B. Knapp. Malden, MA: Blackwell Publishing, 2015.

Maier, F.G. "Evidence for Mycenaean Settlement at Old Paphos." Acts of the International Archaeological Symposium 'The Mycanaeans in the Eastern Mediterranean,' Nicosia 27th March - 2nd April 1972. Nicosia, 1973.

Maier, F.G. "Priest Kings in Cyprus." In Early Society in Cyprus, Edited by E. Peltenburg, 376-391. Edinburgh, 1989.

Muhly, J. D. "Copper and Tin: The Distribution of Mineral Resources and the Nature of the Metals Trade in the Bronze Age." Transactions of the Connecticut Academy of Arts and Sciences 43 (1973).

Muhly, J. D. "The Late Bronze Age in Cyprus: A 25 Year Retrospect." In Archaeology in Cyprus 1960-1985, Edited by V. Karageorghis. Nicosia: Department of Antiquities, 1985.

Muhly, J. D. "The Organization of the Copper Industry in Late Bronze Age Cyprus." In Early Society in Cyprus, Edited by E. Peltenburg. Edinburgh: University of Edinburgh, 1989.

Muhly, J. D. "The Role of Cyprus in the Economy of the Eastern Mediterranean During the Second Millenium B.C." In Acts of the International Archaeological Symposium 'Cyprus Between the Orient and Occident', Edited V. Karageorghis. Nicosia: Department of Antiquities, 1986.

Muhly, J. D., R. Maddin, and V. Karageorghis, Early Metallurgy in Cyprus 4000-500 B.C., Acta of the International Archaeological Symposium, Larnaca. Nicosia: Department of Antiquities, 1981.

Myres, J. L. Handbook of the Cesnola Collection of Antiquities from Cyprus. New York: The Metropolitan Museum of Art, 1914.

Negbi, O. "The Climax of Urban Development in Bronze Age Cyprus." RDAC (1986): 97-121.

Nicolaou, K. "The First Mycenaeans in Cyprus." In Acts of the International Symposiun: The Mycenaeans in the Eastern Mediterranean, Edited by V. Karageorghis. Nicosia: Department of Antiquities, 1973.

Nicolaou, K. The Historical Topography of Kition. SIMA XLIII. Göteborg, 1976. 
Orphanides, A. G. "The Political and Economic Implications of the Mycaenaean Presence in Cyprus." Acts of the Third International Congress of Cypriot Studies. Nicosia, 1985.

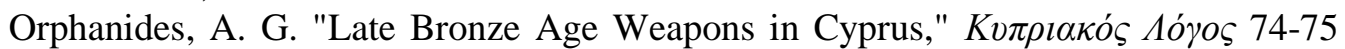
(1981): 178-179.

Orphanides, A. G. "Southern Cyprus in the Late Bronze Age: A Regional Perspective." Archaeologia Cypria I (1985): 23-27.

Keswani, P. Mortuary Rituals and Society in Bronze Age Cyprus. Monographs in Mediterranean Archaeology 9. London: Equinox, 2004.

Panagiotopoulos, D. "The Stirring Sea: Conceptualising Transculturality in the Late Bronze Age Eastern Mediterranean." In Intercultural Contacts in the Ancient Mediterranean, Orientalia Lovaniensia Analecta 202, Edited by K. Duistermaat and I. Regulski. Louvain, 2011.

Plat Taylor du, J. "Mines Where the Mycanaeans Got Their Copper Discovered in Cyprus." ILN 196 (1940).

Pullak, C. "The Bronze Age Shipwreck at Ulu Burun, Turkey: 1985 Campain." AJA 92 (1988): 1-37.

Rabar, P. "Early Copper Production in the Polis Region, Western Cyprus." J Field A 14 (1987): 297-312.

Rabar, P. The Organization and Development of Early Copper Metallurgy in the Polis Region, Western Cyprus. Ph.D. diss., Penn. State Univ., 1984.

Scamborough, L. and J. E. Clark, ed., The Political Economy of Ancient Mesoamerica. Albuquerque: University of New Mexico Press, 2007.

Sherrat, S. "Circulation of Metals and the End of the Bronze Age in the Eastern Mediterranean." In Metals Make the World Go Round: The Supply and Circulation of Metals in Bronze Age Europe, Edited by C. F. Pare. Oxford: Oxbow, 2000.

Sherratt, S. "Immigration and Archaeology: Some Indirect Reflections." In Acta Cypria, Vol. 2, SIMA-PB 117, Edited by P. Åström. Jonsered: Paul Åströms Förlag, 1992.

Smith, C. A. "Regional Economic Systems: Linking Geographical Models and Socioeconomic Problems," in Regional Analysis: Economic Systems, Vol. I, Edited by C.R. Smith. New York: Academic Press, 1976.

Snodgrass, A. M. Arms and Armour of the Greeks. London: Thames and Hudson, 1967.

South, A. "Kalavassos-Ayios Dhimitrios and the Late Bronze Age in Cyprus." In Cyprus at the Close of the Late Bronze Age (1984), Edited V. Karageorgis, R. Maddin and J.D. Muhly, Larnaca: Pierides Foundation 1985.

South, A. K. "From Copper to Kingship: Aspects of Bronze age Society Viewed from the Vasilikos Valley." In Early Society in Cyprus, Edited E. Peltenburg. Edinburgh: University of Edinburgh, 1989.

Stanley Price, N.P. Early Prehistoric Settlement in Cyprus 6500-3000 B.C. BAR, International Series, 65. Oxford, 1979.

Steel, L. "A Rappraisal of the Distribution, Context and Function of Mycaenaean Pottery in Cyprus." In La Ceramique Mycénienne de l'Égée au Levant. Travvaux de la Maison de l' Orient 41, Edited by J. Balensi, J.-Y. Monchambert, and S. Müller-Celku. Lyon: La Maison de l' Orient et de la Mediterranée, 2014.

Steel, L. "Exploring Regional Settlement on Cyprus in the Late Bronze Age: the Rural Hinterland." In The Formation of Cyprus in the 2nd Millennium BC. Studies in 
Regionalism during the Middle and Late Bronze Ages, Edited by I. Hein. Vienna: Austrian Academy of Sciences Press, 2009.

Steel, L. "Late Bronze Age Cyprus." In Oxford Handbook of the Ancient Levant, Edited by M. Steiner and A. Killebrew. Oxford, 2014.

Steel, L. Cyprus before History: From the Earliest Settlers to the End of the Bronze Age. London: Duckworth, 2004.

Stech, T., Maddin, R. and J.D Muhly. "Copper Production at Kition in the Late Bronze Age." Kition I (1985), 388-402.

Stech, T. "Urban Metallurgy in Late Bronze Age Cyprus." EMC. Nicosia, 1981.

Stockhammer, P. W. "Levantine and Cypriot Pottery in Mycenaean Greece as Mirrors of Intercultural Contacts." In The Mediterranean Mirror. Cultural Contacts in the Mediterranean Sea between 1200 and 750 B.C. Conference, Heidelberg, 6th-8th October 2012, RGZM, Edited by A. Babbi et al. Mainz: Schnell und Steiner, 2015.

Stos-Gale, Z. A., N.H. Gale and U. Zwicker. "The Copper Trade in the South-East Mediterranean Region. Preliminary Scientific Evidence." RDAC (1986): 122-144.

Swiny, S. "Bronze Age Settlement Patterns in Southwest Cyprus." Levant 13 (1981): 51-87.

Tylecote, R. F. "The Late Bronze Age Copper and Bronze Metallurgy at Enkomi and Kition." In Early Metallurgy in Cyprus 4000-500 B.C., Acta of the International Archaeological Symposium, Edited by Muhly, J. D., R. Maddin, and V. Karageorghis. Nicosia: Department of Antiquities, 1981.

Vagnetti L. and F.L. Schiavo. "Late Bronze Age Long Distance Trade in the Mediterranean: The Role of the Cypriots." In Early Society in Cyprus, Edited by E. Peltenburg. Edinburgh: University of Edinburgh, 1989.

Vermeule, E. and F. Wolsky. "New Aegean Relations with Cyprus: The Minoan and Mycenaean Pottery from Toumba tou Skourou, Morphou." Proc Amer Phil Soc 122 (1978): 293-317.

Voskos I. and A. B. Knap. "Cyprus at the End of the Late Bronze Age: Crisis and Colonization or Continuity and Hybridization." AJA 112(4) (2008): 659-684.

Wheeler, T. S., J.D. Muhly and R. Maddin, "Mediterranean Trade in Copper and Tin in the Late Bronze Age." Ann Ist It Num 26 (1979): 139-152. 